\title{
Publisher Correction: Orbital bistatic radar observations of asteroid Vesta by the Dawn mission
}

\author{
Elizabeth M. Palmer (10) 1 , Essam Heggy (10 ${ }^{2,3}$ \& Wlodek Kofman ${ }^{4,5}$
}

Nature Communications 8:409 doi:10.1038/s41467-017-00434-6; Article published online 12 September 2017

An incorrect version of the Supplementary Information was inadvertently published with this Article. The HTML has now been updated to include the correct version of the Supplementary Information.

Published online: 23 November 2017

\begin{abstract}
(c) (i) Open Access This article is licensed under a Creative Commons Attribution 4.0 International License, which permits use, sharing, adaptation, distribution and and indicate if changes were made. The images or other third party material in this article are included in the article's Creative Commons license, unless indicated otherwise in a credit line to the material. If material is not included in the article's Creative Commons license and your intended use is not permitted by statutory regulation or exceeds the permitted use, you will need to obtain permission directly from the copyright holder. To view a copy of this license, visit http://creativecommons.org/licenses/by/4.0/.
\end{abstract}

(C) The Author(s) 2017

\footnotetext{
${ }^{1}$ Department of Geosciences, Western Michigan University, 1903 W. Michigan Avenue, Kalamazoo, MI 49008-5241, USA. ${ }^{2}$ Ming Hsieh Department of Electrical Engineering, University of Southern California, 3737 Watt Way, Los Angeles, CA 90089, USA. ${ }^{3}$ Jet Propulsion Laboratory, California Institute of Technology, 4800 Oak Grove Dr., Pasadena, CA 91109, USA. ${ }^{4}$ UGA/CNRS, Institut de Planétologie et d'Astrophysique de Grenoble (IPAG) UMR 5274, Grenoble, F-38041, France. ${ }^{5}$ Space Research Centre of Polish Academy of Sciences, Bartycka 18A, 00-716 Warsaw, Poland Correspondence and requests for materials should be addressed to E.H. (email: heggy@usc.edu)
} 